\title{
DIVERSIFIKASI KOMODITAS PANGAN UNGGULAN LOKAL BERBASIS AGROPOLITAN DI DAERAH KABUPATEN SLEMAN D.I.YOGYAKARTA
}

\author{
Nur Feriyanto ${ }^{1}$, Ilya Fadjar Maharika ${ }^{2}$, Feris Firdaus ${ }^{3}$ \\ Jurusan Ekonomi Pembangunan, Fakultas Ekonomi ${ }^{1}$, Jurusan Arsitektur, Fakultas Teknik Sipil dan \\ Perencanaan ${ }^{2}$, Direktorat Penelitian dan Pengabdian Masyarakat ${ }^{3}$, Universitas Islam Indonesia, \\ Jl. Kaliurang Km.14,5 Sleman, Yogyakarta, 55584 \\ E-Mail:nurferiyanto@yahoo.com ${ }^{1}$, maharika@uii.ac.id ${ }^{2}$,feris.firdaus@uii.ac.id ${ }^{3}$
}

\begin{abstract}
The development of agropolitan areas can deny the false assumption that the developed regions are transformed into urban areas and changes in the dominant role of the agricultural sector to the industrial sector, and services. Assuming that the agricultural sector calculates downstream production up to agro-processing activities, an area can be called advanced by still characterizing the rural areas and the dominant role of the agricultural sector. Based on the results of analysis of excellent potential characteristics with the Sleman region then determined superior food commodities supported by many other commodities. The pre-eminent food commodities are salak fruit located in Turi District and freshwater fish commodities bred in ponds located in Ngemplak sub-district. The two leading food commodities can then be developed into superior products supported by various other food products in order to produce various kinds of food diversification to improve the agropolitanbased rural economy. Based on the results of SWOT analysis related to the potential superior characteristics with the Sleman region then determined superior food commodities supported by many other commodities. The pre-eminent food commodities are salak fruit located in Turi District and freshwater fish commodities bred in ponds located in Ngemplak sub-district. The two leading food commodities can then be developed into superior products supported by various other food products in order to produce various kinds of food diversification to improve the agropolitan-based rural economy. Examples of derivatives of salak pondoh products are salak chips, dodol salak, salak syrup, candied salak, coffee seeds bark and others. Examples of innovations that have been developed is the diversification of catfish and tilapia into catfish abon, catfish chips, crispy tilapia, fish crackers and others that have the durability / durability up to a year more in packaging.
\end{abstract}

Keywords : Diversification, Local Superior Food, Salak Pondoh, Freshwater Fish, Agropolitan.

\section{PENDAHULUAN}

D.I.Yogyakarta telah mengalami perubahan struktur ekonomi yang tercermin dari penurunan peran sektor pertanian dan naiknya peran sektor non pertanian dalam menyumbang produk domestik regional bruto (PDRB) D.I.Yogyakarta. Kondisi tersebut juga berakibat adanya peralihan perkembangan peluang kerja dari sektor pertanian ke sektor non pertanian. Tetapi peralihan peluang kerja ke sektor non pertanian tidak serta merta dapat menampung beralihnya pekerja yang berasal dari sektor pertanian serta angkatan kerja baru yang masuk di sektor non pertanian. Hal ini terjadi karena belum siapnya angkatan kerja dengan keterampilan tenaga kerja yang dibutuhkan sektor non pertanian. Akibatnya penambahan pekerja yang masuk ke sektor pertanian akan menurunkan produktivitasnya, karena marginal produknya bernilai negatif sedangkan pekerja yang masuk ke sektor non pertanian belum maksimal produktivitasnya sehingga secara totalitas bertambahnya pekerja justru bersifat negatif bagi PDRB D.I.Yogyakarta (Feriyanto, 2014).

Dalam laporan Kepala Bidang Ketersediaan Pangan Badan Ketahanan Pangan dan Penyuluhan D.I.Yogyakarta (2013) disebutkan bahwa sebanyak 80 desa yang tersebar diempat kabupaten di 
D.I.Yogyakarta rawan pangan. Desa rawan pangan tersebar di empat kabupaten masingmasing di Sleman (12 desa), Gunungkidul (24 desa), Kulonprogo (34 desa), dan Bantul (10 desa). Desa - desa yang masuk kategori rawan pangan itu dilihat tidak hanya dari ketersediaan pangannya namun juga terkait kecukupan gizi, dan kemiskinan. Selain diversifikasi pangan, di desa rawan pangan juga dibentuk lembaga akses pangan sebagai solusi hambatan distribusi pangan yang menjadi pemicu desa menjadi rawan pangan. Sulitnya akses menuju desa tersebut, menjadi masalah dalam distribusi pangan sehingga masyarakat susah menjangkau pangan. Penentuan desa rawan pangan dinilai berdasarkan tiga indikator yakni ketersediaan pangan, akses pangan (kemiskinan) dan pemanfaatan pangan (kesehatan) (Arjayanti, 2013).

Penentuan desa rawan pangan dinilai berdasarkan tiga indikator yakni ketersediaan pangan, akses pangan (kemiskinan) dan pemanfaatan pangan (kesehatan). Di D.I.Yogyakarta desa yang dikategorikan rawan pangan karena disebabkan oleh salah satu indikator saja. Penyebab terbesar desa rawan di D.I.Yogyakarta adalah kemiskinan (akses pangan). Untuk mengurangi desa rawan pangan yang karena indikator akses pangan, harus dilakukan pengentasan kemiskinan. Desa rawan pangan dengan indikator pemanfaatan pangan ini bisa dilihat dari kecukupan gizi yang kurang. Di D.I.Yogyakarta Kecukupan kalori karbohidrat sekitar $96 \%$ sedangkan kecukupan kalori nasional 98\%. Sementara itu kecukupan kalori protein sudah melampaui yakni 104\%. Di tahun 2015, Badan Ketahanan Pangan dan Penyuluhan (BKPP) D.I.Yogyakarta selain mengurangi desa rawan pangan juga akan mengurangi desa waspada pangan sebanyak 16 desa yaitu masing - masing tujuh desa di Kabupaten Kulonprogo dan Sleman serta masing masing satu desa di Kabupaten Bantul dan Gunungkidul (Indriani, 2014).
Konsep pengembangan agropolitan muncul dari permasalahan adanya ketimpangan pembangunan wilayah antara kota sebagai pusat kegiatan dan pertumbuhan ekonomi dengan wilayah perdesaan sebagai pusat kegiatan pertanian yang tertinggal. Proses interaksi ke dua wilayah selama ini secara fungsional ada dalam posisi saling memperlemah. Wilayah perdesaan dengan kegiatan utama sektor primer, khususnya pertanian, mengalarni produktivitas yang selalu menurun akibat beberapa permasalahan, di sisi lain wilayah perkotaan sebagai tujuan pasar dan pusat pertumbuhan menerima beban berlebih sehingga memunculkan ketidaknyamanan akibat permasalahan permasalahan sosial (konflik, kriminal, dan penyakit) dan lingkungan (pencernaran dan buruknya sanitasi lingkungan permukiman). Hubungan yang saling memperlemah ini secara agregat wilayah keseluruhan akan berdampak pada penurunan produktivitas wilayah (Rustiadi dan Hadi, 2008).

Pembangunan sektor pertanian dan wilayah perdesaan sekarang dianggap sangat penting, karena apabila pembangunan sektor ini di wilayah tersebut menjadi tidak berhasil dikembangkan, terutarna dalam jangka menengah dan jangka panjang, dapat memberi dampak negatif terhadap pembangunan nasional keseluruhannya, berupa terjadinya kesenjangan yang semakin melebar antar wilayah dan antar kelompok tingkat pendapatan. Kemampuan sektor pertanian untuk memberikan kontribusi secara langsung terhadap pertumbuhan ekonomi dan kesejahteraan rumah tangga tani tergantung pada tingkat pendapatan usaha tani dan surplus yang dihasilkan dari sektor pertanian itu sendiri. Dengan demikian, tingkat pendapatan usahatani, disamping merupakan penentu utama kesejahteraan rumah tangga petani, juga muncul sebagai salah satu faktor penting yang mengkondisikan pertumbuhan pertanian. 
Tingkat pendapatan usaha tani ini sangat ditentukan oleh efisiensi petani untuk mengalokasikan sumber daya yang dimilikinya kedalam berbagai alternatif aktivitas produksi.

\section{METODE PENELITIAN}

Metode penelitian

tentang pengembangan diversifikasi pangan lokal berbasis agropolitan untuk penguatam ekonomi perdesaan serta mampu menopang kebutuhan produk pangan alternatif di daerah kabupaten Sleman D.I.Yogyakrta menggunakan pendekatan Pengembangan Agropolitan sebagai Strategi Pembangunan Pedesaan dan Pembangunan Berimbang (Rustiadi dan Hadi, 2008), Pengembangan Kawasan Agropolitan Dalam Rangka Pengembangan Wilayah (Soenarno, 2008), yang dilandasi oleh Kebijakan Teknis Program Pengembangan Usaha Agribisnis Perdesaan untuk Penguatan Ekonomi Perdesaan (Departemen Pertanian, 2008), Development : Toward a New Strategy for Regional Planning in Asia (Fiedman and Douglas, 1975), Territory and Function : The Evolution of Regional Planning (Friedman and Weaver, 1979), The Role of Small and intermediate Sized City in National Development Processes and Strategies (Hansen, 1982), Applied Methods of Regional Analysis The Spatial Dimensions of Development Policy (Rondinelli, 1985).

Penelitian dilakukan di daerah kabupaten Sleman D.I.Yogyakarta dan difokuskan pada klaster kawasan perdesaan di 2 (dua) kecamatan yang memiliki potensi besar di bidang pertanian pangan dan daya dukung lainnya yang terkait, yakni kecamatan Turi dan kecamatan Ngemplak kabupaten Sleman D.I.Yogyakarta. Sampel ditentukan dengan metode convenience sampling. Convenience sampling merupakan sampel non probailitas yang tidak terbatas, dimana sampel dipilih dari anggota populasi yang paling mudah untuk ditemui dan dimintai informasi (Hadi, 1987, Cooper dan Emory, 1991). Penelitian ini didukung oleh data primer yang diperoleh secara langsung dilokasi sampel dan didukung juga dengan data sekunder yang diperoleh dari stakeholders terkait di lokasi sampel.

\section{HASIL DAN PEMBAHASAN}

Produksi tanaman buah - buahan di Kabupaten Sleman didominasi oleh salak pondoh, sesuai dengan predikat yang disandang selama ini sebagai produsen salak pondoh terbesar. Produksi salak pondoh pada tahun 2015 mencapai 696.995 kwintal, naik sekitar 0,05 persen dibanding tahun sebelumnya sebanyak 662.321 kwintal. Komoditas ini sebagian besar dibudidayakan di Kecamatan Turi, Tempel dan Pakem yang produksinya mencapai 97,51 persen dari total produksi Kabupaten Sleman. Sementara itu, produksi Salak Gading 2.572 kwintal dan Salak Biasa 38.873 kwintal (BPS Kabupaten Sleman 2015). Selain dijual dalam bentuk buah, salak pondoh juga dapat dijual dalam bentuk olahan yang sudah dikreasikan menjadi dodol salak, manisan salak, kripik salak, dan aneka makanan lainnya. Selain itu perkebunan salak pondoh juga dapat dijadikan tempat wisata seperti yang terjadi di Dusun trumpon, Desa Merdikorejo, Kecamatan Tempel, Kabupaten Sleman.Potensi dari salak pondoh ini sangat besar untuk terus dapat dikembangkan di Kabupaten Sleman karena menjadi salah satu komoditi andalan.

Produksi ikan air tawar (kolam) tersentral di kawasan Kecamatan Ngemplak. Budidaya Ikan di Kabupaten Sleman terdiri dari budidaya ikan dikolam air tawar dan budidaya ikan dikolam air sawah yang dikenal dengan mina padi. Sedangkan untuk budidaya diperairan umum (karamba) masih digabung dengan penangkapan ikan di perairan umum. Produksi ikan di Kabupaten Sleman didominasi oleh budidaya di kolam air tawar, yaitu $30.750 .540 \mathrm{~kg}$. Budidaya mina padi dan perairan umum hanya menghasilkan masing - masing $151.900 \mathrm{~kg}$ dan $218.060 \mathrm{~kg}$ (BPS Kabupaten Sleman 2015). Usaha perikanan di Kabupaten Sleman pada saat ini merupakan kegiatan / usaha pokok masyarakat Sleman. Dengan kata lain pada saat ini banyak masyarakat Sleman yang bermata pencaharian pokok 
Tabel 1. Matrik Analisis SWOT Dalam Rangka Menentukan Asumsi - Asumsi Strategi Berbasis Produk Unggulan Salak Pondoh Di Kabupaten Sleman

\begin{tabular}{|c|c|c|}
\hline Faktor I & $\begin{array}{l}\text { Kekuatan (S) } \\
\text { 1. Sumber Daya Alam ( iklim, } \\
\text { tanah, air ) mendukung untuk } \\
\text { usahatani salak pondoh. } \\
\text { 2. Pengalaman Petani tehnis } \\
\text { usahatani komoditas salak } \\
\text { pondoh cukup baik. } \\
\text { 3. Adanya Kelembagaan Petani. } \\
\text { 4. Adanya Modal Gapoktan. } \\
\text { 5. Kualitas produk bersaing. }\end{array}$ & \begin{tabular}{l}
\multicolumn{1}{c}{ Kelemahan (W) } \\
1. Tenaga Kerja Kurang. \\
2. \\
Pengetahuan petani tentang Pasca \\
panen (diversifikasi produk) masih \\
terbatas. \\
3. Peranan Pemuda pada usahatani \\
salak pindoh kurang. \\
4. Modal produksi diversifikasi \\
produk turunan Kurang. \\
5. Manajemen pemasaran produk \\
belum maksimal.
\end{tabular} \\
\hline Peluang (O) & $\begin{array}{r}\text { Memanfaatk } \\
\text { memanf: }\end{array}$ & $\begin{array}{r}\text { Meminimall } \\
\text { meman }\end{array}$ \\
\hline $\begin{array}{l}\text { 1. Adanya Kebijakan } \\
\text { Pemerintah } \\
\text { Mewujudkan Sistem } \\
\text { Pertanian yang sehat, } \\
\text { Mandiri, kompetitif dan } \\
\text { Lestari. } \\
\text { 2. Permintaan pasar } \\
\text { terhadap komoditisalak } \\
\text { pondoh dan produk } \\
\text { turunannyacukup tinggi. } \\
\text { 3. Kemitraan terbuka. } \\
\text { 4. Adanya Kredit Usaha } \\
\text { Rakyat. informasi } \\
\text { 5. Tersedianya inang } \\
\text { teknologi kegiatan } \\
\text { mendukung } \\
\text { usahatani salak pondoh. }\end{array}$ & 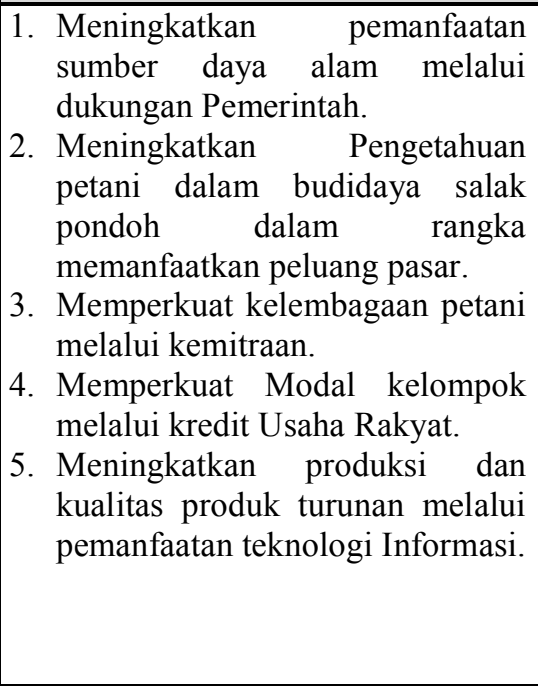 & \begin{tabular}{|l} 
1. $\begin{array}{l}\text { Memanfaatkan kebijakan } \\
\text { pemerintah dalam rangka } \\
\text { mengatasi kurangnya tenaga kerja. }\end{array}$ \\
2. $\begin{array}{l}\text { Meningkatkan Pengetahuan Petani } \\
\text { tentang penanganan pasca panen } \\
\text { (diversifikasi produk) untuk }\end{array}$ \\
memenuhi permintaan pasar yang \\
cukup tinggi. \\
3. Meningkatkana peran pemuda tani \\
untuk melakukan kemitraan. \\
4. Menumbuhkan kelembagaan \\
Pemuda Tani guna memanfaatkan \\
kredit usaha rakyat. \\
5. Memnfaatkan Teknologi Informasi \\
dalam rangka pengembangan \\
pasar.
\end{tabular} \\
\hline Ancaman (T) & $\begin{array}{l}\text { Memanfaatkan kekuatan untuk } \\
\text { Mengurangi ancaman }\end{array}$ & $\begin{array}{c}\text { Meminimalkan Kelemahan untuk } \\
\text { mengurangi ancaman }\end{array}$ \\
\hline $\begin{array}{l}\text { 1. Generasi muda petani } \\
\text { beralih ke sektor lain } \\
\text { 2. Perubahan iklim dan } \\
\text { cuaca yang tidak } \\
\text { menentu. } \\
\text { 3. Alih fungsi lahan } \\
\text { pertanian } \\
\text { pemukiman. } \\
\text { 4. Serangan Hama Penyakit } \\
\text { 5. Adanya pemasok salak } \\
\text { pondoh di daerah lain. }\end{array}$ & 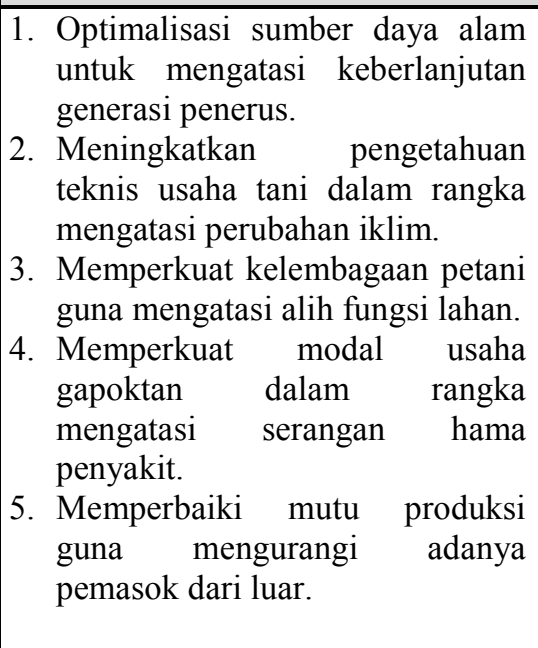 & 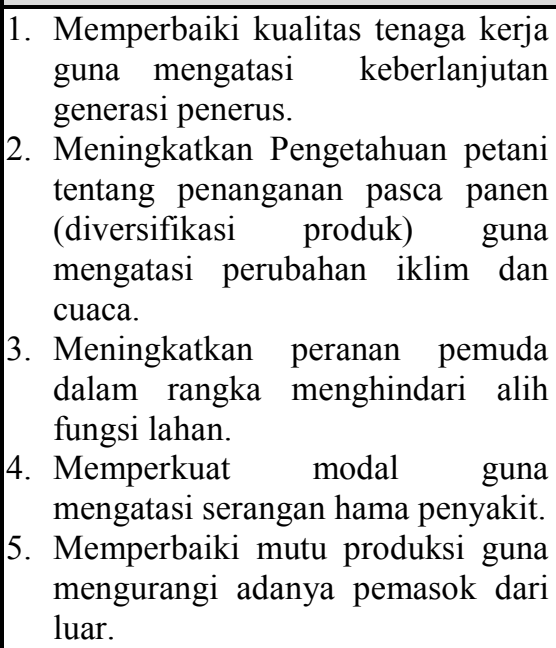 \\
\hline
\end{tabular}


Tabel 2. Matrik Analisis SWOT Dalam Rangka Menentukan Asumsin - Asumsi Strategi Berbasis Produk Unggulan Ikan Air Tawar Di Kabupaten Sleman

\begin{tabular}{|c|c|c|}
\hline \multirow[b]{2}{*}{ Faktor Eksternal } & Kekuatan (S) & \multirow[b]{2}{*}{$\begin{array}{l}\text { Kelemahan (W) } \\
\text { 1. Tenaga Kerja Kurang. } \\
\text { 2. Pengetahuan petani tentang Pasca } \\
\text { panen (diversifikasi produk) masih } \\
\text { terbatas. } \\
\text { 3. Peranan Pemuda pada usahatani } \\
\text { ikan air tawar kurang. } \\
\text { 4. Modal produksi diversifikasi } \\
\text { produk turunan Kurang. } \\
\text { 5. Manajemen pemasaran produk } \\
\text { belum maksimal. }\end{array}$} \\
\hline & $\begin{array}{l}\text { 1. Sumber Daya Alam ( iklim, } \\
\text { tanah, air ) mendukung untuk } \\
\text { usahatani ikan air tawar. } \\
\text { 2. Pengalaman Petani tehnis } \\
\text { usahatani komoditas ikan air } \\
\text { tawar cukup baik. } \\
\text { 3. Adanya Kelembagaan Petani. } \\
\text { 4. Adanya Modal Gapoktan. } \\
\text { 5. Kualitas produk bersaing. }\end{array}$ & \\
\hline Peluang (O) & $\begin{array}{c}\text { Memanfaatkan kekuatan untuk } \\
\text { memanfaatkan Peluang }\end{array}$ & $\begin{array}{l}\text { Meminimalkan kelemahan untuk } \\
\text { memanfaatkan Peluang }\end{array}$ \\
\hline $\begin{array}{l}\text { 1. Adanya Kebijakan } \\
\text { Pemerintah } \\
\text { Mewujudkan Sistem } \\
\text { Pertanian yang sehat, } \\
\text { Mandiri, kompetitif dan } \\
\text { Lestari. } \\
\text { 2. Permintaan pasar } \\
\text { terhadap komoditi ikan air } \\
\text { tawar dan produk } \\
\text { turunannya cukup tinggi. } \\
\text { 3. Kemitraan terbuka. } \\
\text { 4. Adanya Kredit Usaha } \\
\text { Rakyat. informasi } \\
\text { 5. Tersedianya yang } \\
\text { teknologi kegiatan } \\
\text { mendukung inan } \\
\text { usahatani ikan air tawar. }\end{array}$ & \begin{tabular}{|l} 
1. \\
Meningkatkan pemanfaatan \\
sumber daya alam melalui \\
dukungan Pemerintah. \\
2. \\
Meningkatkan Pengetahuan \\
petani dalam budidaya ikan air \\
tawar dalam rangka \\
memanfaatkan peluang pasar. \\
3. Memperkuat kelembagaan petani \\
melalui kemitraan. \\
4. \\
Memperkuat Modal kelompok \\
melalui kredit Usaha Rakyat. \\
5. Meningkatkan produksi dan \\
kualitas produk turunan melalui \\
pemanfaatan teknologi Informasi.
\end{tabular} & $\begin{array}{l}\text { 1. Memanfaatkan kebijakan } \\
\text { pemerintah dalam rangka mengatasi } \\
\text { kurangnya tenaga kerja. } \\
\text { 2. Meningkatkan Pengetahuan Petani } \\
\text { tentang penanganan pasca panen } \\
\text { (diversifikasi produk) untuk } \\
\text { memenuhi permintaan pasar yang } \\
\text { cukup tinggi. } \\
\text { 3. Meningkatkana peran pemuda tani } \\
\text { untuk melakukan kemitraan. } \\
\text { 4. Menumbuhkan kelembagaan } \\
\text { Pemuda Tani guna memanfaatkan } \\
\text { kredit usaha rakyat. } \\
\text { 5. Memnfaatkan Teknologi Informasi } \\
\text { dalam rangka pengembangan pasar. }\end{array}$ \\
\hline Ancaman (T) & $\begin{array}{l}\text { Memanfaatkan kekuatan untuk } \\
\text { Mengurangi ancaman }\end{array}$ & $\begin{array}{c}\text { Meminimalkan Kelemahan untuk } \\
\text { mengurangi ancaman }\end{array}$ \\
\hline $\begin{array}{l}\text { 1. Generasi muda petani } \\
\text { beralih ke sektor lain. } \\
\text { 2. Perubahan iklim dan } \\
\text { cuaca yang tidak } \\
\text { menentu. } \\
\text { 3. Alih fungsi lahan } \\
\text { perikanan } \\
\text { pemukiman. } \\
\text { 4. Serangan Hama Penyakit. } \\
\text { 5. Adanya pemasok ikan air } \\
\text { tawar di daerah lain. }\end{array}$ & \begin{tabular}{|l} 
1. Optimalisasi sumber daya alam \\
untuk mengatasi keberlanjutan \\
generasi penerus. \\
2. Meningkatkan pengetahuan \\
teknis usaha tani dalam rangka \\
mengatasi perubahan iklim. \\
3. Memperkuat kelembagaan petani \\
guna mengatasi alih fungsi lahan. \\
4. Memperkuat modal usaha \\
gapoktan dalam rangka \\
mengatasi serangan hama \\
penyakit. \\
5emperbaiki mutu produksi \\
guna mengurangi adanya \\
pemasok dari luar.
\end{tabular} & $\begin{array}{l}\text { 1. Memperbaiki kualitas tenaga kerja } \\
\text { guna mengatasi keberlanjutan } \\
\text { generasi penerus. } \\
\text { 2. Meningkatkan Pengetahuan petani } \\
\text { tentang penanganan pasca panen } \\
\text { (diversifikasi produk) guna } \\
\text { mengatasi perubahan iklim dan } \\
\text { cuaca. } \\
\text { 3. Meningkatkan peranan pemuda } \\
\text { dalam rangka menghindari alih } \\
\text { fungsi lahan. } \\
\text { 4. Memperkuat modal guna mengatasi } \\
\text { serangan hama penyakit. } \\
\text { 5. Memperbaiki mutu produksi guna } \\
\text { mengurangi adanya pemasok dari } \\
\text { luar. }\end{array}$ \\
\hline
\end{tabular}


dari perikanan. Pada akhir tahun 2013 tercatat sebanyak 507 kelompok tani ikan dengan 5 Balai Benih Ikan dan 1 UPTD Perikanan. Wilayah Sleman juga cocok untuk budidaya ikan air tawar. Berdasarkan data yang ada perkembangan perikanan di Sleman ini sampai sekarang menunjukkan prospek yang bagus. Pada tahun 2013 produksi ikan konsumsi mencapai 25.530,3 ton (meningkat 4 ton lebih dibandingkan tahun sebelumnya), benih ikan 947 juta ekor lebih. Pada tahun 2015 meningkat lagi menjadi 30.750,54 (meningkat hampir 5 ton dari tahun sebelumnya) (BPS Kabupaten Sleman 2015).

Berdasarkan hasil analisis SWOT (lihat Tabel 1-2) terkait potensi unggulan yang karakteristik dengan kawasan Sleman maka ditentukan komoditas pangan unggulan yang didukung banyak komoditas lainnya. Komoditas pangan unggulan tersebut adalah buah salak yang berada di kawasan Kecamatan Turi dan komoditas ikan air tawar yang dikembangbiakkan dikolam yang berada dikawasan Kecamatan Ngemplak. Dua komoditas pangan unggulan ini selanjutnya dapat dikembangkan menjadi produk unggulan yang didukung berbagai produk pangan lainnya dalam rangka menghasilkan berbagai macam diversifikasi pangan untuk meningkatkan ekonomi perdesaan berbasis agropolitan. Berkut ini adalah matrik analisis SWOT dalam rangka menentukan asumsi-asumsi strategi berbasis produk unggulan salak pondoh dan ikan air tawar di Kabupaten Sleman.

Berdasarkan hasil analisis potensi unggulan yang karakteristik dengan kawasan Sleman maka ditentukan komoditas pangan unggulan yang didukung banyak komoditas lainnya. Komoditas pangan unggulan tersebut adalah buah salak yang berada di kawasan Kecamatan Turi dan komoditas ikan air tawar yang dikembangbiakkan di kolam yang berada di kawasan Kecamatan Ngemplak. Dua komoditas pangan unggulan ini selanjutnya dapat dikembangkan menjadi produk unggulan yang didukung berbagai produk pangan lainnya dalam rangka menghasilkan berbagai macam diversifikasi pangan untuk meningkatkan ekonomi perdesaan berbasis agropolitan.

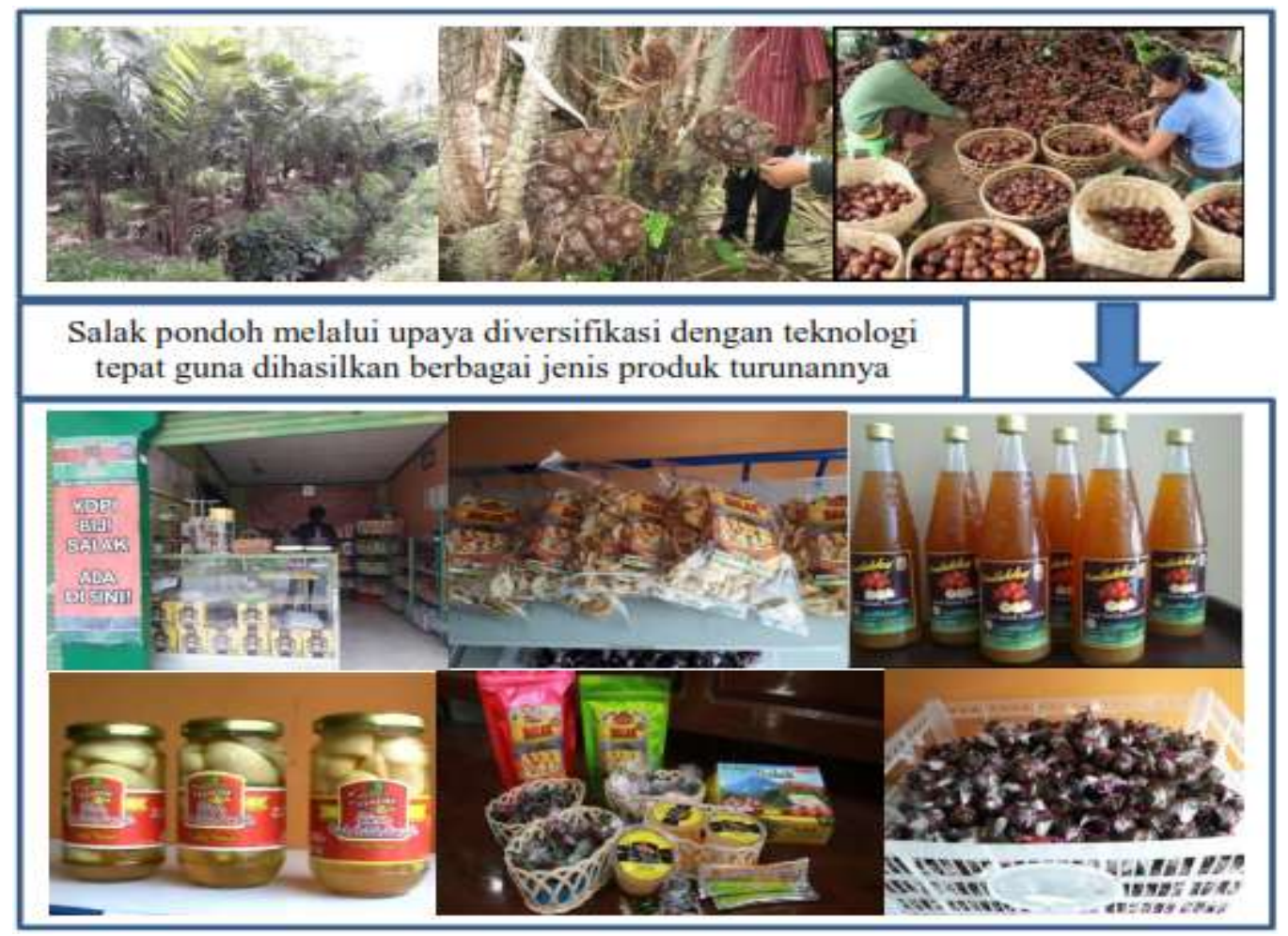

Gambar 1. Diversifikasi Salak Pondoh Menjadi Produk Turunannya (Sleman). 
Tampak dalam gambar 1 tersebut bahwa salah satu produk unggulan di Kecamatan Turi Kabupaten Sleman adalah salak pondoh yang sangat melimpah. Kelimpahan salak pondoh ini di musim panen menyebabkan harga penjualan salak pondoh segar menjadi turun sehingga diperlukan upaya diversifikasi produk salak pondoh menjadi berbagai macam produk turunan salak pondoh yang lebih tahan lama dan dapat dipasarkan sepanjang tahun. Contoh produk turunan salak pondoh tersebut adalah kripik salak, dodol salak, sirup salak, manisan salak, kopi biji salak dan lain - lain. Inovasi ini harus terus dikembangkan dengan sentuhan teknologi tepat guna menjadi beragam produk turunan lainnya yang bernilai ekonomi tinggi untuk menopang kebutuhan pangan lokal yang lebih banyak dan berdaya saing tinggi yang pada akhirnya dapat meningkatkan perekonomian masyarakat. Dalam gambar 2 berikut ini ditampilkan produk unggulan lainnya dari Kabupaten Sleman yakni ikan air tawar yang kelimpahannya sangat besar yang tersentral di Kecamatan Ngemplak Kabupaten Sleman. Tampak dalam gambar 2 tersebut bahwa salah satu produk unggulan di Kecamatan Ngemplak Kabupaten Sleman adalah ikan air tawar khususnya ikan nila dan ikan lele yang sangat melimpah.

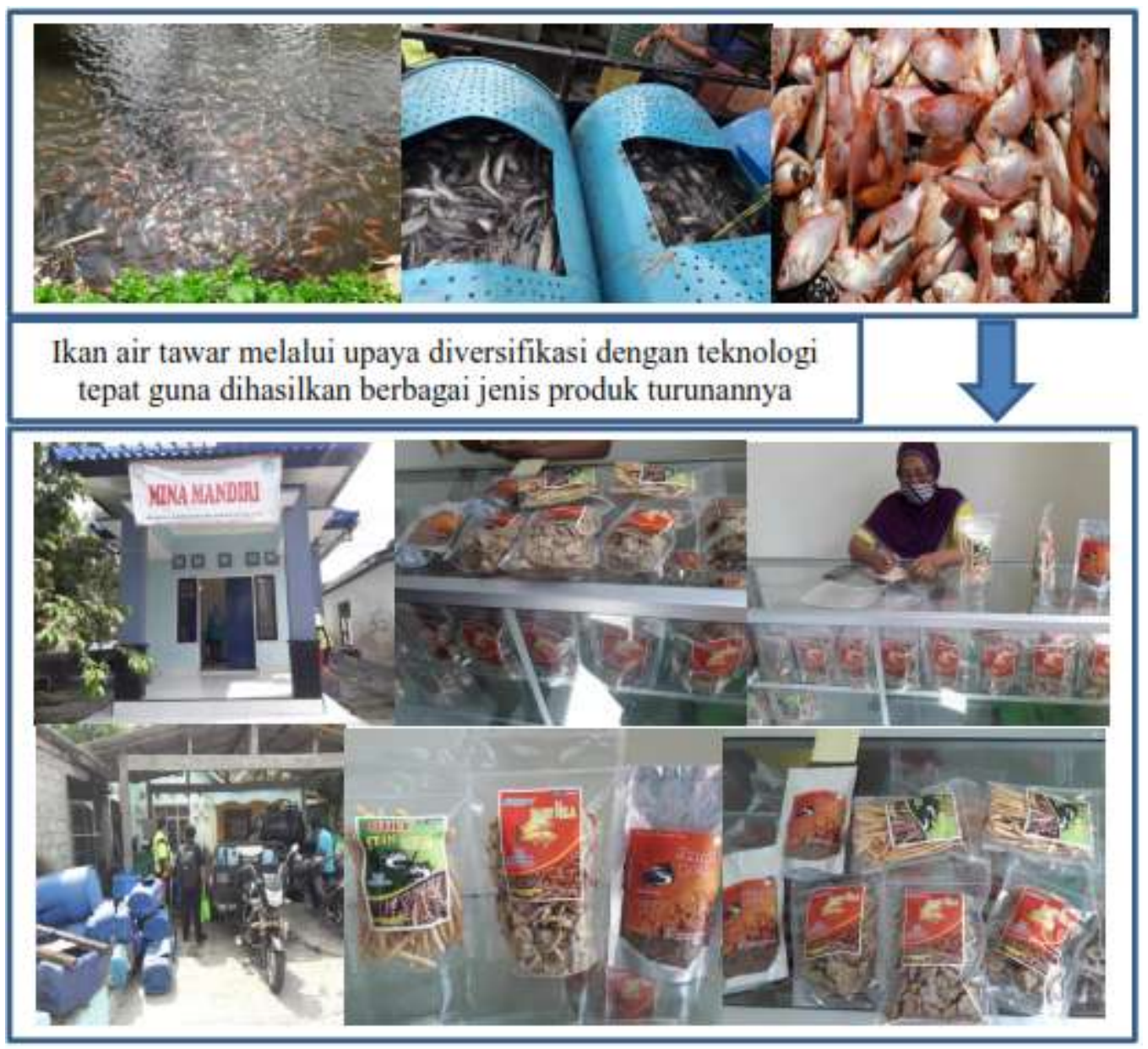

Gambar 2. Diversifikasi Ikan Air Tawar Menjadi Produk Turunannya (Sleman). 
Walaupun kelimpahan ikan air tawar khususnya ikan nila dan ikan lele ini besar di musim panen namun tidak mempengaruhi harga penjualan karena dua jenis ikan air tawar tersebut merupakan jenis ikan konsumsi yang paling banyak digemari untuk kelas ikan air tawar dengan harga terjangkau. Untuk meningkatkan nilai ekonomi kedua jenis ikan ini maka diperlukan upaya diversifikasi dengan sentuhan teknologi tepat guna menjadi produk turunan yang bernilai ekonomi lebih tinggi dibanding ikan yang dijual dalam kondisi segar. Contoh hasil inovasi yang sudah dikembangkan adalah diversifikasi ikan lele dan ikan nila menjadi abon lele, keripik lele, nila crispy, kerupuk ikan dan lain - lain yang memiliki ketahanan / keawetan sampai setahun lebih dalam kemasan. Inovasi ini harus terus dikembangkan dengan sentuhan teknologi tepat guna menjadi beragam produk turunan lainnya yang bernilai ekonomi tinggi untuk menopang kebutuhan pangan lokal yang lebih banyak dan berdaya saing tinggi yang pada akhirnya dapat meningkatkan perekonomian masyarakat.

Selain sentuhan teknologi tepat guna sebagi upaya diversifikasi produk turunan baik salak pondoh maupun ikan air tawar sebagai produk unggulan di Kabupaten Sleman, diperlukan strategi yang tepat untuk meningkatkan pemasaran produk turunan hasil diversifikasi tersebut. Sampai saat ini proses pemasaran produk hasil diversifikasi tersebut dipasarkan secara konvensional dan sangat terbatas diwilayah Sleman D.I.Yogyakarta saja. Kapasitas produksinya juga masih sangat terbatas karena bergantung pada permintaan pasar lokal yang terbatas selain karena modal usaha yang sangat terbatas.
Upaya peningkatan daya serap produk hasil diversifikasi tersebut perlu ditingkatkan dengan membuka jalur pemasaran yang lebih luas melalui berbagai media baik pasar tradisional, pasar moderen, maupun pasar online (internet) yang dapat diakses secara nasional bahkan internasional. Diharapkan 2 (dua) komoditas unggulan daerah Sleman tersebut serta berbagai macam produk turunannya dapat menopang kebutuhan pangan alternatif lokal untuk ketahanan pangan nasional.

Pengembangan kawasan agropolitan dapat menyangkal asumsi yang keliru bahwa kawasan yang maju adalah kawasan yang bertransformasi menjadi perkotaan dan perubahan peranan dominan sektor pertanian ke sektor industi, dan pelayanan. Dengan asumsi bahwa sektor pertanian perhitungan produksinya sampai ke hilir yaitu sampai kepada kegiatan agro processing, maka suatu wilayah dapat disebut maju dengan tetap mencirikan wilayah perdesaan dan peran sektor pertanian yang tetap dominan.

\section{KESIMPULAN}

Berdasarkan hasil analisis SWOT terkait potensi unggulan yang karakteristik dengan kawasan Sleman maka ditentukan komoditas pangan unggulan yang didukung banyak komoditas lainnya. Komoditas pangan unggulan tersebut adalah buah salak yang berada dikawasan Kecamatan Turi dan komoditas ikan air tawar yang dikembang biakkan dikolam yang berada di kawasan Kecamatan Ngemplak. Dua komoditas pangan unggulan ini selanjutnya dapat dikembangkan menjadi produk unggulan yang didukung berbagai produk pangan lainnya dalam rangka menghasilkan berbagai macam diversifikasi pangan untuk meningkatkan ekonomi perdesaan berbasis agropolitan. 
Salah satu produk unggulan di Kecamatan Turi Kabupaten Sleman adalah salak pondoh yang sangat melimpah. Contoh produk turunan salak pondoh tersebut adalah kripik salak, dodol salak, sirup salak, manisan salak, kopi biji salak dan lain - lain. Salah satu produk unggulan di Kecamatan Ngemplak Kabupaten Sleman adalah ikan air tawar khususnya ikan nila dan ikan lele yang sangat melimpah. Contoh hasil inovasi yang sudah dikembangkan adalah diversifikasi ikan lele dan ikan nila menjadi abon lele, keripik lele, nila crispy, kerupuk ikan dan lain - lain yang memiliki ketahanan / keawetan sampai setahun lebih dalam kemasan.

\section{Ucapan Terimakasih}

Ucapan terimakasih disampaikan kepada Direktorat Riset dan Pengabdian Masyarakat Kementerian Riset, Teknologi dan Pendidikan Tinggi RI yang telah membiayai penelitian ini dalam skema Penelitian Terapan Unggulan Perguruan Tinggi (PTUPT) pada tahun anggaran 2016 - 2017.

\section{DAFTAR PUSTAKA}

Arjayanti, S., 2013. 80 Desa Di Yogyakartaa Masuk Kawasan Rawan Pangan, Bidang Ketersediaan Pangan Badan Ketahanan Pangan Dan Penyuluhan Diy, Http : // Www.Tribunnews.Com/Regional 2013 / 11 / 01 / 80 - Desa-DiYogyakarta-Masuk-KawasanRawan-Pangan.

Cooper, DR dan CW Emory., 1991. Business Research Method, 5" ed. Richard D Irwin Inc, Chicago.
Departemen Pertanian., 2008. Pedoman Umum Pemberdayaan dan Pengembangan Usaha Agribisnis Lembaga Mandiri yang Mengakar di Masyarakat (LM3). Departemen Pertanian, Jakarta.

Feriyanto, N., 2014. Analisis Pengaruh Jumlah Orang Bekerja, Investasi, dan Jumlah Wisatawan Terhadap PDRB Daerah Istimewa Yogyakarta, Economic Journal of emerging Markets ISSN 2086-3128, Vol.6, Issue 2, Edisi Oktober 2014 (Jurnal Terakreditasi Dikti).

Feriyanto, N., 2014. Ekonomi Sumber Daya Manusia, Buku, ISBN 9789793532875. Cetakan I, Maret 2014. UPP STIM YKPN Yogyakarta.

Fiedman, John and Mike Douglas., 1975. Development: Toward a New Strategy for Regional Planning in Asia. Regional Economic Centre. Nagoya. Japan.

Friedman, J. and Weaver C., 1979. Territory and FunctionThe Evolution of Regional Planning. Edward Arnold (Publisher) Ltd. London.

Hadi, SW., 1987. Metodologi Riset, Jilid 1, Yayasan Penerbit Fakultas Psikologi UGM, Yogyakarta.

Hansen, Niles., 1982. The Role of Small and intermediate Sized Citlea in National Development Processes and Strategies. Paper delivered at Expert roup Meeting on The role of small and intertmediate cities in National development. UNCRD. Nagoya, Japan. 
Indriani, A.N., 2014. Di Diy, Hanya Tinggal 26 Desa Rawan Pangan, Badan Ketahanan Pangan Dan Penyuluhan (Bkpp), Http www.Republika.Co.Id/Berita/Nasio nal/Daerah /14 / 12 / 22 / NgzezdDi-Diy-Hanya-Tinggal-26-DesaRawan-Pangan.

Rondinelli, A. Dennis., 1985. Applied Methods of Regional Analysis The Spatial Dimensions of Development Policy. Westview Press / Boulder. London.

Rustiadi, Ernan dan Setia Hadi., 2008. Pengembangan Agropolitan Sebagai Strategi Pembangunan Perdesaan Dan Pembangunan Berimbang, Proyek Strategis Ditjen Cipta Karya RI.

Soenarno., 2008. Pengembangan Kawasan Agropolitan Dalam Rangkaian Pengembangan Wilayah, Proyek Strategis Ditjen Cipta Karya RI. 